\title{
MODEL PENCIPTAAN LAPANGAN PEKERJAAN MELALUI PENGEMBANGAN EKONOMI LOKAL PADA KECAMATAN KELAPA LIMA KOTA KUPANG
}

\author{
Oleh : \\ Hapsa Usman*
}

\begin{abstract}
Abstrak
Penelitian ini dilakukan di Kecamatan kelapa lima yang memiliki 6 kelurahan dengan luas wilayah 15,31 KM2 dan jumlah penduduk 61.411 orang. Dengan memiliki banyak kekhasan lokal yang dapat di bina dan di manfaatkan menjadi ekonomi lokal bagi peningkatan pendapatan masyarakat dan daerah yang bersangkutan. Hasil pertanian, kerajinan kerajinan, home industri seperti gula lempeng dan sebagainya dapat dikembangkan menjadi daya tarik ekonomi lokal baik pada tataran daerah maupun nasional.

Penelitian ini dilaksanakan pada 3 kelurahan yang ada di di Kecamatan kelapa lima dengan obyek potensi usaha masyarakat. Tujuan penelitian adalah untuk mengidentifikasi potensi sumberdaya ekonomi lokal yang berdaya tarik, berdaya saing tinggi dan berpotensi menciptakan lapangan pekerjaan. Data dikumpulkan melalui focus group discussion dengan masyarakat. Metode analisis yang digunakan adalah analisis deskriptif kualitatif pendekatan Analisa SWOT.

Hasil penelitian menunjukkan bahwa banyak sektor usaha yang secara berturut-turut adalah : perikanan, perdagangan, industri rumah tangga dan jasa, pertanian dan peternakan sangat menjanjikan karena lokasi daerahnya sangat strategis. Ditinjau dari Jenis produk unggulannya berupa hasil Kelautan berupa ikan, makanan \& minuman tradisional, kerajinan gula lempeng, jasa fotocopy dan Rental serta rumah makan. Hasil analisa SWOT menjelaskan bahwa ada beberapa kekuatan dan kelemahan masyarakat ekonomi lokal yakni sumber daya ekonomi lokal sangat potensi dan jumlah bahan baku serta tenaga kerja yang melimpah namun tidak adanya perhatian dan dukungan dari pemerintah dalam mengembangkan masyarakat didaerah ini, sementara itu peluang Dan ancaman yang ada di kecamatan kelapa lima diantaranya adalah minat dan kebutuhan masyarakat semakin banyak dan daya saing semakin tinggi. Untuk itu perlu adanya kerjasama dari berbagai pihak antara lain pemerintah, Bank, Lsm, Perguruan Tinggi dan Pengusaha dalam mengembangkan dan meningkatkan masyarakat ekonomi Lokal ini.
\end{abstract}

Kata kunci: Ekonomi lokal, daya saing, daya tarik, lapangan kerja.

\section{POLITEKNIK NEGERI KUPANG}

| ISSN 2528-0651 


\title{
Desember
}

\begin{abstract}
Abstrak
This research was conducted in the district that has coconut five six villages with an area of $15.31 \mathrm{~km} 2$ and a population of 61411 people. By having lots of local peculiarities that can be cultivated and utilized into the local economy to improve household incomes and the region concerned. Agricultural products, handicrafts crafts, home industries such as sugar plate and so on can be developed to attract local economy both at local and national levels.

The research was conducted in three villages in the District of coconut in five with the object of public business potential. The purpose of research is to identify the resource potential of the local economy a powerful attraction, highly competitive and has the potential to create jobs. Data were collected through focus group discussion with the community. The analytical method used is descriptive qualitative analysis SWOT analysis approach.

The results showed that the business sector consecutively are: fisheries, trade, domestic industry and services, agriculture and animal husbandry are very promising because the location is very strategic region. Judging from the type form of the Marine superior products such as fish and traditional food \& beverage, sugar craft plate, photocopy services and Rental and restaurants. The SWOT analysis explains that there are some strengths and weaknesses of the community local economies that local economic resources very potential and the amount of raw materials and labor is abundant, but the lack of attention and support from the government in developing the community in this area, while the opportunities and threats that exist in the district of coconut five of which are the interests and needs of the people more and more and higher competitiveness. For that we need the cooperation of various stakeholders, including the government, the Bank, NGOs, universities and employers in developing and improving local community's economy.
\end{abstract}

Keywords: Local economy, competitiveness, attractiveness, employment.

*)Hapsa Usman; Dosen Program Studi Akuntansi Sektor Publik Politeknik Negeri Kupang.

\section{PENDAHULUAN}

Pembangunan ekonomi daerah adalah suatu proses di mana pemerintah daerah dan masyarakatnya mengelola sumber daya yang ada dan membentuk suatu pola kemitraan antara pemerintah daerah dengan sektor swasta untuk menciptakan suatu lapangan kerja baru dan merangsang perkembangan pertumbuhan ekonomi dalam wilayah tersebut (Mudrajat, 2004, h.120). Setiap

\section{POLITEKNIK NEGERI KUPANG}

| ISSN 2528-0651 


\section{Desember}

upaya pembangunan ekonomi daerah mempunyai tujuan utama untuk meningkatkan jumlah dan jenis peluang kerja untuk masyarakat daerah.Pembangunan ekonomi daerah dapat dimulai pada pembangunan daerah pedesaan pada umum nya dan sektor pertanian dan kelautan pada khusunya karena keduanya sama sekali tidak bersifat pasif dan sekedar penunjang dalam proses pembangunan ekonomi secara keseluruhan.

\section{Program Blue Economy 2013} yang mengedepankan Pemanfaatan wilayah pedesaan yang memiliki pesisir pantai dan lautan Provinsi NTT sangat potensil dan beragam, baik dari usaha perikanan (tangkap, budidaya dan pengolahan, Pengelolaan) juga pariwisata (bahari dan Alam, Budaya), yang pemanfaatan sumber daya ini belum optimal.

Kota kupang dengan jumlah penduduk miskin pada tahun 2010 sebanyak 61.100 orang, sedangkan pada tahun 2011 angka kemiskinan masyarakat kota kupang naik menjadi 61.200. dan meningkat lagi pada tahun 2012 menajdi 61.900 jiwa. Dengan melihat angak kemiskinan yang dari waktu ke waktu semakin meningkat, pada hal pemerintah tiap tahun mengucurkan program hibah pemberdayaan masyarakat miskin, tapi angka miskin semakin bertambah . (sumber: profile Kota Kupang 2012).
Kecamatan kelapa lima memiliki 6 kelurahan dengan luas wilayah 15,31 KM2 dan jumlah penduduk 61.411 orang. Dengan memiliki banyak kekhasan lokal yang dapat di bina dan di manfaatkan menjadi ekonomi lokal bagi peningkatan pendapatan masyarakat dan daerah yang bersangkutan. Hasil pertanian, kerajinan kerajinan, home industri seperti gula lempeng dan sebagainya dapat dikembangkan menjadi daya tarik ekonomi lokal baik pada tataran daerah maupun nasional.

Penyebab tingginya angka kemiskinan disebab-kan oleh banyaknya pendatang yang tidak berbekal keterampilan serta banyaknya lulusan sekolah dan perguruan tinggi yang tidak tertampung di lapangan pekerjaan (Indra, 2009). Selain itu, tingginya angka kemiskinan juga disebabkan oleh karena banyak hal baik dari aspek pemerintah, masyarakat, pencari kerja aktif dan para lulusan PT yang belum memiliki pekerjaan, sehingga mengakibat-kan bertambahnya jumlah pengangguran.

Salah satu usaha untuk mengatasi masalah kemiskinan yang efektif sesuai rekomendasi ILO No 189 tahun 1998 tentang General conditions for the promotion of job creation through small and medium-sized enterprises adalah dengan penciptaan lapangan kerja. Akses ke lapangan pekerjaan adalah jalan yang paling menjamin untuk bisa keluar dari kemiskinan. Dengan demikian, kebijakan dan program penciptaan lapangan kerja tetap memainkan peran penting dalam 
memerangi kemiskinan. Rekomendasi tersebut sebagai dasar untuk mengubah dan meninggalkan model pengentasan kemiskinan yang bersifat top-down dari pemerintah terhadap masyarakat miskin menjadi buttom-up. Semua kebijakan yang diambil pemerintah harus pro-poor (ILO, 2004).

Berdasarkan rekomendasi ILO No. 189, maka peneliti mencoba untuk menerapkan model pencipta-an lapangan kerja melalui pengembangan ekonomi lokal pada Kecamatan Kelapa Lima karena daerah masih menduduki peringkat terjelek untuk masyarakat miskin.. Permasalahan utama pada penelitian ini Bagaimana potensi sumberdaya ekonomi lokal yang berdaya tarik, dan berpotensi menciptakan lapangan pekerjaan, Faktor faktor apa sajakah penghambat berkembangnya Ekonomi Lokal masyarakat pesisir pantai, Bagaimana model Penciptaan Lapangan Kerja Bagi Ekonomi Lokal Masyarakat Pesisir Kelapa Lima.

Tujuan dari penelitian ini adalah Mengidentifikasi potensi sumberdaya ekonomi lokal yang berdaya tarik, berdaya saing tinggi dan berpotensi menciptakan lapangan pekerjaan, Faktor faktor penghambat berkembangnya ekonomi Lokal ikembangkan dan dapat meningkatkan ekonomi masyarakat pesisir pantai, dan Merumuskan model Penciptaan Lapangan kerja Bagi Masyarakat kelapa Lima .

LANDASAN TEORI

1. Pengertian Ekonomi Lokal

Menurut Blakely and Bradshaw PEL adalah proses dimana pemerintah lokal dan organsisasi masyarakat terlibat untuk mendorong, merangsang, memelihara, aktivitas usaha untuk menciptakan lapangan pekerjaan.

Sementara itu menurut International Labour Organization (ILO) PEL adalah proses partisipatif yang mendorong kemitraan antara dunia usaha dan pemerintah dan masyarakat pada wilayah tertentu, yang memungkinkan kerjasama dalam perancangan dan pelaksanaan strategi pembangunan secara umum, dengan menggunakan sumber daya local dan keuntungan kompetitif dalam konteks global, dengan tujuan akhir menciptakan lapangan pekerjaan yang layak dan merangsang kegiatan ekonomi. Menurut A. H. J. Helming mengemukakan PEL adalah suatu proses dimana kemitraan yang mapan antara pemerintah daerah, kelompok berbasis masyarakat, dan dunia usaha mengelola sumber daya yang ada untuk menciptakan lapangan pekerjaan dan merangsang (pertumbuhan) ekonomi pada suatu wilayah tertentu. Menekankan pada kontrol lokal, dan penggunaan potensi sumber daya manusia, kelembagaan dan sumber daya fisik.

\section{Pengertian wilayah pesisir}

Para pemikir social berpendapat bahwa wilayah pesisir juga dapat lepas dari permasalahan sosial ekonomi masyarakat pesisir.Sehingga batas pesisir tidak hanya didasarkan pada pendekatan biologis dan pengaruh langsung dari lingkungannya. Wilayah pesisir sampai 
jauh menjangkau kearah darat tidak hanya sampai ke lokasi permukiman, tetapi meluas sampai ke mata pencaharian penduduk yang masih berkaitan dengan produksi kelautan.

\section{Fokus PEL}

- Peningkatan kandungan lokal; stakeholders secara substansial $\mathrm{dlm}$ kemitraan strategis;

- Peningkatan ketahanan dan kemandirian ekonomi; Pembangunan bekeberlanjutan;

- Pemanfaatan hasil pembangunan oleh masyarakat lokal; Pengembangan UMKM

- Pertumbuhan ekonomi yang dicapai secara inklusif;

- Penguatan kapasitas dan peningkatan kualitas sumber daya manusia;

- Pengurangan kesenjangan antar golongan masyarakat, antar sektor dan daerah

- Pengurangan dampak negatif dari kegiatan ekonomi terhadap lingkungan.

\section{Dimensi PEL}

(1) Pengertian lokal yang terdapat dalam definisi PEL tidak merujuk pada batasan wilayah administratif tetapi lebih pada peningkatan kandungan komponen lokal maupun optimalisasi pemanfaatan sumberdaya lokal. (2) PEL sebagai inisiatif daerah yang dilakukan secara partisipatif. (3) PEL menekankan pada pendekatan pengembangan bisnis, bukan ada pendekatan bantuan sosial yang bersifat karikatif. (4) PEL bukan merupakan upaya penanggulangan kemiskinan secara langsung. (5) PEL diarahkan untuk mengisi dan mengoptimalkan kegiatan ekonomi yang dilakukan berdasarkan pengembangan wilayah, pewilayahan komoditas, tata ruang, atau regionalisasi ekonomi.

\section{Tujuan dan Sasaran PEL}

- Terlaksananya upaya percepatan pengembangan ekonomi lokal melalui pelibatan pemerintah, dunia usaha, masyarakat lokal, dan organisasi masyarakat madani dalam suatu proses yang partisipatif.

- Terbangun dan berkembangnya kemitraan dan aliansi strategis dalam upaya percepatan pengembangan ekonomi lokal diantara stakeholder secara sinergis.

- Terbangunnya sarana dan prasarana ekonomi yang mendukung upaya percepatan pengembangan ekonomi lokal.

- Terwujudnya pengembangan dan pertumbuhan UKM secara ekonomis dan berkelanjutan.

- Terwujudnya peningkatan PAD dan PDRB.

- Terwujudnya peningkatan pendapatan masyarakat, berkurangnya pengangguran, menurunnya tingkat kemiskinan.

- Terwujudnya peningkatan pemerataan antar kelompok masyarakat, antar sektor dan antar wilayah. 
- Terciptanya ketahanan dan kemandirian ekonomi masyarakat lokal.

6. Kelompok Sasaran

Investor luar, Pelaku Usaha Lokal , Pelaku Usaha Baru Berupa Pelatihan kewirausahaan, pendampingan \& monitoring, insentif, kecepatan ijin

\section{METODE PENELITIAN}

Lokasi Penelitian berada di Kecamatan Kelapa Lima dengan 5 kelurahan secara geografis dan orisinalitas memiliki aneka obyek dan kekayaan daerah yang bisa dijadikan sebagai ekonomi lokal sebagai sumber pendapatan masyaraakat yang selama ini belum di berdayakan. Potensi potensi ekonomi lokal yang berada di beberapa kelurahan di kecamatan kelapa lima seperti potensi kelautan, pertanian, kerajinan, dan aneka kuliner yang ada di lokasi ini yang sebenarnya tumbuh dengan sendiri tetapi tidak diperhatikan dan dikembangkan sehingga hanya sebagai suatu kesibukan masyakrakat dalam memenuhi kebutuhan hidupnya. Jenis penelitian deskritif Dalam penelitian ini digunakan teknik observasi, wawancara, dan quesioner serta studi literatur dan dokumen dan Fokus Group discussion Masyarakat, Populasi adalah seluruh masyarakat yang melakukan usaha kecil dan Mikro mengandung ekonomi lokal yang berdaya tarik dan berdaya saing tinggi yang ada di kecamatan Kelapa lima dan dengan teknik Purposive Sampling. Fokus penelitian pada potensi usaha masyarakat Kelapa Lima yang didukung dengan data lingkung-an, kewilayahan, sosial, ekonomi dan budaya serta demografi. Sampel yang dipilih adalah kelompok usaha kecil masyarakat di sektor dagang, jasa, industri rumah tangga, pertanian, peternakan di 5 (lima) kelurahan di wilayah Kecamatan Kelapa Lima dengan jumlah sample adalah berdasarkan sektor usaha 60 responden. Dengan teknik Analisis Data secara Deskritif Kuantitatif dan Analisa SWOT. Kerangka penelitian pada Gambar 3 sebagai berikut:

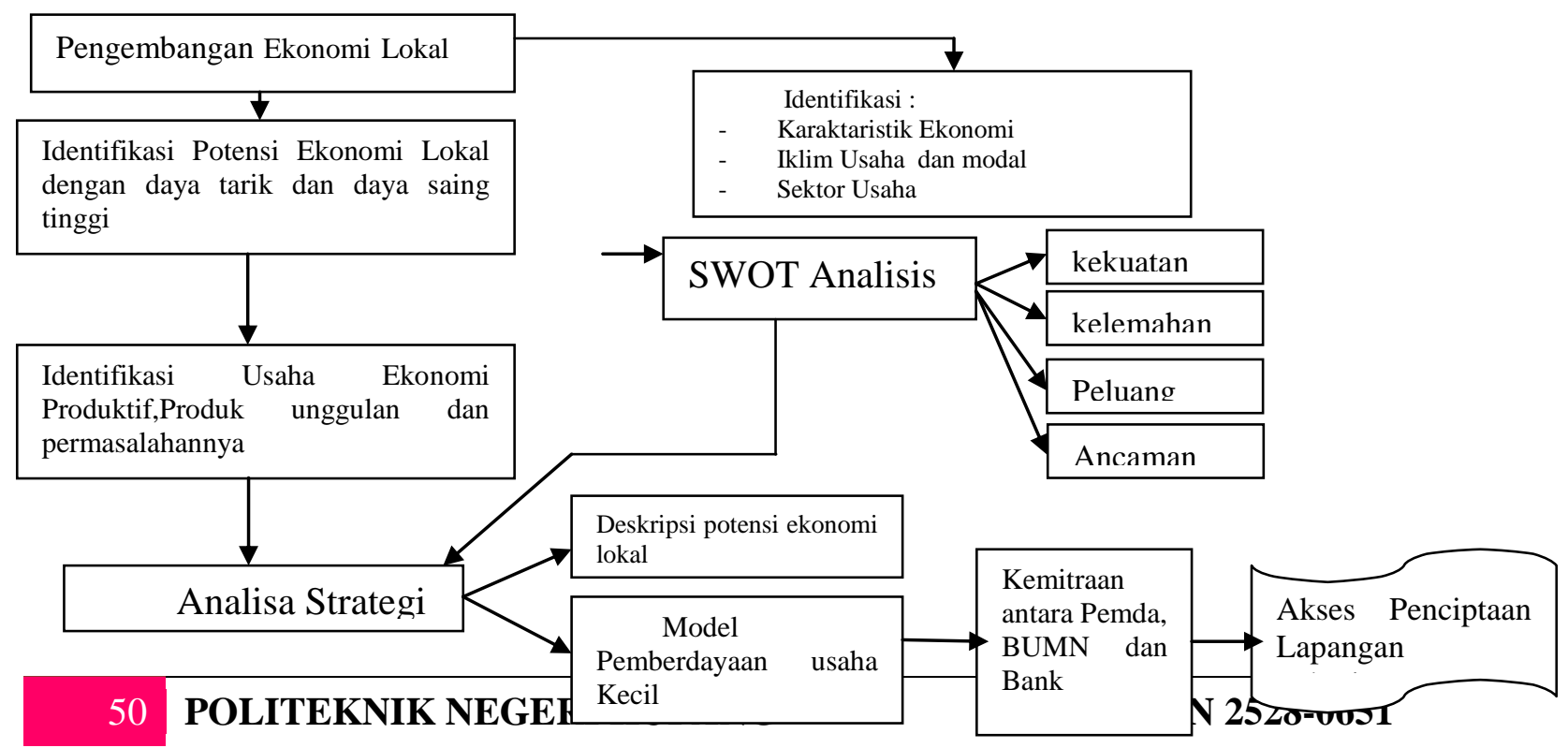


1. GAMBARAN KECAMATAN KELAPA LIMA

Kecamatan Kelapa Lima adalah Salah satu Kecamatan dari 6 (enam) kecamatan yang berada dalam wilayah Pemerintah Kota Kupang yang terletak membujur dari timur ke barat yang berada pada ketingggian $50 \mathrm{~m}$ diatas permukaan laut, dengan batas-batas wilayah sebagai berikut :

- Sebelah Utara berbatasan dengan Teluk Kupang

- Sebelah Selatan berbatasan dengan Kecamatan Oebobo

- Sebelah Timur berbatasan dengan Kecamatan Kupang Tengah

- Sebelah Barat berbatasan dengan Kecamatan Kota Lama

Luas Wilayah Kecamatan Kelapa Lima adalah 15,02 $\mathrm{KM}^{2}$ dengan kepadatan penduduk 4.575 per km2.

Hal ini dapat dirincikan dalam luas per 5 Kelurahan di Kecamatan Kelapa Lima. Terdapat 18.981 KK yang terdapat dalam wilayah Kecamatan Kelapa Lima dengan Jumlah RT/RW Terdapat 167 rukun tetangga (RT), 58 rukun warga $(\mathrm{RW})$.

\section{POTENSI} MASYARAKAT LIMA

Mata pencaharian penduduk kecamatan Kelapa Lima secara umum dapat dibedakan dalam tiga kategori yaitu Perikanan, Perdagangan, dan pertanian . Mata pencaharian terbesar adalah dari sektor Perikanan dan perdagangan karena masyarakat adalah nelayan. Data mata pencaharian penduduk kecamatan Kelapa Lima dapat dilihat dalam tabel berikut:

Tabel 4 Komposisi Mata Pencaharian Penduduk

\begin{tabular}{|r|l|r|r|r|}
\hline & \multicolumn{1}{|c|}{ MATA } & \multicolumn{1}{c|}{ L } & \multicolumn{1}{c|}{ P } & \multicolumn{1}{c|}{ JUMLAH } \\
\hline 1 & PNS & 2744 & 1817 & 4561 \\
\hline 2 & TNI & 183 & 9 & 192 \\
\hline 3 & POLRI & 319 & 53 & 372 \\
\hline 4 & PNS POLRI/TNI & 47 & 6 & 53 \\
\hline 5 & GURU & 570 & 790 & 1360 \\
\hline 6 & DOSEN & 459 & 176 & 635 \\
\hline 7 & DOKTER & 111 & 240 & 351 \\
\hline
\end{tabular}

\section{POLITEKNIK NEGERI KUPANG}

| ISSN 2528-0651 
JURNAL AKUNTANSI, KEUANGAN DAN AUDIT

\begin{tabular}{|c|c|c|c|c|}
\hline 8 & BIDAN/MANTRI & 22 & 28 & 50 \\
\hline 9 & PETANI/NELAYAN & 1849 & 507 & 2356 \\
\hline 10 & NELAYAN & 204 & 0 & 204 \\
\hline 11 & PENGEMUDI & 774 & 2 & 776 \\
\hline 12 & TUKANG SERVICE/MONTIR & 1340 & 0 & 1340 \\
\hline 13 & PEDAGANG & 1156 & 819 & 1975 \\
\hline 14 & PENSIUNAN PNS & 556 & 247 & 803 \\
\hline 15 & PENSIUNAN POLRI & 80 & 7 & 87 \\
\hline 16 & ANGGOTA DEWAN & 5230 & 7027 & 12257 \\
\hline 17 & MENGURUS RUMAH TANGGA & 0 & 6096 & 6096 \\
\hline 18 & MAHASISWA/PELAJAR & 10266 & 8179 & 18445 \\
\hline 19 & ANGGOTA DEWAN & 6 & 1 & 7 \\
\hline 20 & PENGACARA & 8 & 2 & 10 \\
\hline 21 & BURUH & 1409 & 256 & 1665 \\
\hline 22 & PENDETA & 36 & 35 & 71 \\
\hline 23 & PASTOR & 25 & 0 & 25 \\
\hline 24 & ULAMA & 9 & 0 & 9 \\
\hline 25 & WIRASWASTA & 2502 & 1400 & 3902 \\
\hline 26 & WARTAWAN & 17 & 4 & 21 \\
\hline 27 & BELUM BEKERJA & 2805 & 2694 & 5499 \\
\hline 28 & TIDAK BEKERJA & 2035 & 1622 & 3657 \\
\hline \multirow[t]{2}{*}{29} & PEGAWAI SWASTA & 1002 & 993 & 1995 \\
\hline & JUMLAH & 35764 & 33010 & 64819 \\
\hline
\end{tabular}

Sumber: Data Lapangan Diolah Penulis

\section{KARAKTATISTIK RESPONDEN ( Tabel 6)}

\begin{tabular}{|c|c|c|c|}
\hline \multirow[t]{2}{*}{ No } & \multirow[t]{2}{*}{ Variabel } & \multicolumn{2}{|c|}{ Masy Kelapa Lima } \\
\hline & & Populasi (N) & $\%$ \\
\hline \multirow[t]{4}{*}{1.} & Jenis kelamin & & \\
\hline & a. Laki laki & 29 & 48,33 \\
\hline & b. Perempuan & 31 & 51,66 \\
\hline & Jumlah & 60 & 100 \\
\hline \multirow[t]{6}{*}{2.} & Usia & & \\
\hline & a. $\quad<17$ thn & 2 & 3,33 \\
\hline & b. $\quad 17-25$ thn & 18 & 30 \\
\hline & c. $\quad 26-50 \mathrm{Thn}$ & 32 & 53,33 \\
\hline & d. $>50$ & 8 & 13,33 \\
\hline & Jumlah & 60 & 100 \\
\hline 3. & Daerah Asal & & \\
\hline
\end{tabular}




\begin{tabular}{|c|c|c|c|}
\hline & a. Dalam kota & 29 & 48,33 \\
\hline & b. Luar Kota & 31 & 51,66 \\
\hline & Jumlah & 60 & 100 \\
\hline \multirow[t]{9}{*}{4.} & Pendidikan terakhir & & \\
\hline & Tidak tamat SD & 4 & 6,66 \\
\hline & b. Tamat SD & 10 & 16,66 \\
\hline & c. $\quad$ Tamat SMP & 20 & 33,33 \\
\hline & d. Tamat SMA/SMEA & 15 & 25 \\
\hline & e. Diploma & 6 & 10 \\
\hline & Sarjana & 4 & 6,66 \\
\hline & $\begin{array}{ll}\text { g. } & \text { Pasca Sarjana } \\
\end{array}$ & 1 & 1,66 \\
\hline & Jumlah & 60 & 100 \\
\hline \multirow[t]{8}{*}{5.} & Pekerjaan & & \\
\hline & a. Pengusaha & 5 & 35 \\
\hline & b. Pemilik Warung & 10 & 12,5 \\
\hline & c. Petani & 11 & 3,75 \\
\hline & d. $\quad$ Nelayan & 12 & 3,75 \\
\hline & e. $\quad$ Pedagang & 14 & 25 \\
\hline & f. Pengrajin & 8 & 3,75 \\
\hline & Jumlah & 60 & 100 \\
\hline \multirow[t]{6}{*}{6.} & Pendapatan & & \\
\hline & a. $\quad<$ Rp 2 juta & 10 & 12 \\
\hline & b. $\quad$ Rp. 2 juta -4 juta & 29 & 36,25 \\
\hline & c. $\quad$ Rp 4 juta -6 juta & 20 & 25 \\
\hline & d. $\quad>$ Rp. 6.juta & 21 & 26,25 \\
\hline & Jumlah & 60 & 100 \\
\hline \multirow[t]{7}{*}{7.} & Tujuan Usaha & & \\
\hline & a. Kelangsungan Hidup & 38 & 47,5 \\
\hline & b. Melanjutkan Usaha & 6 & 7,5 \\
\hline & c. Mencari ketenangan & 12 & 15 \\
\hline & d. $\quad$ Bisnis & 20 & 25 \\
\hline & e. Lainnya & 5 & 5 \\
\hline & Jumlah & 80 & 100 \\
\hline \multirow[t]{6}{*}{8.} & Alat Transportasi & & \\
\hline & a. $\quad$ Mobil pribadi & 38 & 47,5 \\
\hline & b. $\quad$ Motor & 18 & 22,5 \\
\hline & c. $\quad$ Bus /Travel & 21 & 26,25 \\
\hline & d. Angkutan Umum & 3 & 3,75 \\
\hline & Jumlah & 80 & 100 \\
\hline
\end{tabular}

Sumber : data diolah penulis

\section{a. Analisis Kekuatan dan Kelemahan}

Tabel 7 Analisis Kekuatan dan Kelemahan

\begin{tabular}{|c|c|c|c|}
\hline No. & Variabel Internal & Skor & Kategori \\
\hline \multirow[t]{4}{*}{1.} & \multicolumn{3}{|l|}{ Strength (Kekuatan) } \\
\hline & Potensi Ekonomi Lokal & 3 & Sangat Potensil \\
\hline & Tingkat Pendapatan usaha & 3 & Baik \\
\hline & Kondisi Fasilitas Usaha & 2 & Baik \\
\hline
\end{tabular}


JURNAL AKUNTANSI, KEUANGAN DAN AUDIT

\begin{tabular}{|c|c|c|c|}
\hline & Fasilitas Pendukung Usaha ekonomi Lokal & 3 & Tersedia \\
\hline & Lahan Yang diberikan Pemerintah & 3 & Tersedia \\
\hline & Aspek Bahan Baku & 3 & Sangat Baik \\
\hline & Kondisi Masyarakat ekonomi Lokal & 3 & Sangat Aktif \\
\hline & Jumlah Produksi Barang Dan Jasa & 3 & Cukup Tinggi \\
\hline & Proses Pasar dan lokasi pasar & 3 & Sangat Baik \\
\hline & Tingkat Penetapan harga & 2 & Bersaing \\
\hline & Jumlah Nilai & 28 & \\
\hline \multirow[t]{13}{*}{2.} & Weakness (Kelemahan) & & \\
\hline & Kebersihan Lingkungan Usaha Ekonomi Lokal & 1 & Kurang terawat \\
\hline & Tingkat Pendidikan Pedagang dan Penjual & 1 & Rendah \\
\hline & Kemampuan Kewirausahaan & 1 & Rendah \\
\hline & Modal Usaha & 1 & Rendah \\
\hline & Sarana Jalan Untuk Usaha & 1 & Kurang Baik \\
\hline & Ketersediaan Lampu penerangan dan Petunjuk & 1 & Belum Tersedia \\
\hline & Fasilitas Usaha Ekonomi Lokal & 1 & Tidak Lengkap \\
\hline & Tingkat Keamanan dalam Proses Usaha & 1 & Kurang Aman \\
\hline & Ketersediaan Teknology & 1 & Kurang tersedia \\
\hline & Jaringan Air dan Listrik & 1 & Kurang Lancar \\
\hline & Penguasaan Ketrampilan usaha & 1 & Rendah \\
\hline & Jumlah & 11 & \\
\hline
\end{tabular}

Sumber Data: hasil Penelitian 2015

\section{b. Analisis Peluang dan Ancaman}

Tabel 8

Analisis Peluang dan Ancaman

\begin{tabular}{|c|c|c|c|}
\hline No. & Variabel Ekternal & Skor & Kategori \\
\hline \multirow[t]{7}{*}{1.} & \multicolumn{3}{|l|}{ Opportunity (Peluang) } \\
\hline & Minat dan Jumlah Pembeli & 3 & Selalu Meningkat \\
\hline & Kebijakan Pemerintah TTg Usaha Ekonomi Lokal & 3 & Tinggi \\
\hline & Pemasaran Usaha Ekonomi Lokal & 3 & Besar \\
\hline & Jumlah Barang dan Jasa & 3 & Banyak \\
\hline & Pengelolaan Areal Usaha Ekonomi Lokal & 3 & Cukup Potensial \\
\hline & Bahan Baku Melimpah & 3 & Tinggi \\
\hline
\end{tabular}

\section{POLITEKNIK NEGERI KUPANG}


JURNAL AKUNTANSI, KEUANGAN DAN AUDIT

\begin{tabular}{|c|c|c|c|}
\hline & Jumlah Usaha Beraneka Ragam & 3 & Sangat Bagus \\
\hline & Pasar dan Pemasaran Terbuka Lebar & 3 & Cukup \\
\hline & Keberadaaan Lokasi Usaha & 3 & Sangat strategis \\
\hline & Lapangan Usaha Tenaga Kerja & 3 & Sangat Bagus \\
\hline & Jumlah Nilai & 30 & \\
\hline \multirow[t]{10}{*}{2.} & Threat (Ancaman) & & \\
\hline & Persaingan Pasar Usaha Kecil & 1 & Lemah \\
\hline & Kondisi Ekonomi dan Politik serta kemanan & 1 & Lemah \\
\hline & Konflik Ruang dengan kegiatan perikanan & 1 & Kurang terkoordinir \\
\hline & Pencemaran Lingkungan karena tidak ada perawatan & 1 & Belum terawat \\
\hline & Koordinasi antara Pelaku usaha dan beberapa sektor lemah & 1 & Kurang Baik \\
\hline & Pemerintah Membuat Program Hanya Sebatas Slogan & 2 & Kurang tegas \\
\hline & Koordinasi Antara Dunia Usaha dgn Pemerintah tak sejalan & 2 & Kurang Sejalan \\
\hline & Softs kill dan Hardskill Masyarakat Ekonomi Lokal & 1 & Rendah \\
\hline & Jumlah & 10 & \\
\hline
\end{tabular}

Sumber Data: hasil Penelitian 2015

\section{c. Analisis Efas dan Ifas}

Tabel 9

Matrix IFAS (Internal Factors Analisys Summary)

\begin{tabular}{|c|c|c|c|c|}
\hline Variabel Internal & Bobot & Rating & Skor & Komentar \\
\hline \multicolumn{5}{|l|}{ Strength (S) } \\
\hline Potensi Ekonomi Lokal & 0,13 & 4 & 0,56 & Sangat Bagus \\
\hline Tingkat Pendapatan usaha & 0,11 & 3 & 0,36 & Tinggi \\
\hline Kondisi Fasilitas Usaha & 0,05 & 3 & 0,33 & Baik \\
\hline Fasilitas Pendukung Usaha ekonomi & 0,08 & 3 & 0,24 & Tersedia \\
\hline Lahan Yang diberikan Pemerintah & 0,03 & 4 & 0,36 & Sangat bagus \\
\hline Aspek Bahan Baku & 0,05 & 4 & 0,32 & Tersedia \\
\hline Kondisi Masyarakat ekonomi Lokal & 0,02 & 4 & 0,08 & Baik \\
\hline Jumlah Produksi Barang Dan Jasa & 0,05 & 3 & 0,15 & Banyak \\
\hline Proses Pasar dan lokasi pasar & 0,02 & 3 & 0,21 & Baik \\
\hline Tingkat Penetapan harga & 0,05 & 3 & 0,15 & Bersaing \\
\hline Sub Total & 0,54 & & 2,56 & \\
\hline \multicolumn{5}{|l|}{ Weaaknesses (W) } \\
\hline Kebersihan Lingkungan Usaha & 0,05 & 1 & 0,05 & Kurang baik \\
\hline Tingkat Pendidikan Pedagang & 0,04 & 2 & 0,18 & Rendah \\
\hline Kemampuan Kewirausahaan & 0,04 & 1 & 0,07 & Rendah \\
\hline
\end{tabular}


JURNAL AKUNTANSI, KEUANGAN DAN AUDIT

\begin{tabular}{|l|c|c|c|c|}
\hline Modal Usaha & 0,03 & 1 & 0,03 & Kecil \\
\hline Sarana Jalan Untuk Usaha & 0,06 & 2 & 0,18 & Kurang Terawat \\
\hline Ketersediaan Lampu dan Petunjuk & 0,03 & 1 & 0,03 & Kurang Nyaman \\
\hline Fasilitas Usaha Ekonomi Lokal & 0,02 & 1 & 0,02 & Kurang Tersedia \\
\hline Tingkat Keamanan Proses Usaha & 0,05 & 2 & 0,1 & Kurang Aman \\
\hline Ketersediaan Teknology & 0,06 & 1 & 0,06 & Kurang lancar \\
\hline Jaringan Air dan Listrik & 0,03 & 1 & 0,04 & Tidak Jelas \\
\hline Sub Total & 0,41 & & 0,56 & 2,00 \\
\hline Jumlah Total S dan W & 1,00 & & & \\
\hline
\end{tabular}

Sumber Data: hasil Penelitian 2015

Tabel 10

Matrix EFAS (Ekternal factors Analisys Summary)

\begin{tabular}{|c|c|c|c|c|}
\hline Variabel Internal & Bobot & Rating & Skor & Komentar \\
\hline \multicolumn{5}{|l|}{ Oportunity $(\mathrm{O})$} \\
\hline Minat dan Jumlah Pembeli & 0,15 & 4 & 0,60 & Sangat tinggi \\
\hline $\begin{array}{l}\text { Kebijakan Pemerintah TTg Usaha Ekonomi } \\
\text { Lokal }\end{array}$ & 0,11 & 3 & 0,36 & Sangat Besar \\
\hline Pemasaran Usaha Ekonomi Lokal & 0,05 & 3 & 0,15 & Peluang tinggi \\
\hline Jumlah Barang dan Jasa & 0,11 & 3 & 0,33 & Harapan yang baik \\
\hline Pengelolaan Areal Usaha Masy & 0,03 & 4 & 0,36 & Sangat bagus \\
\hline Bahan Baku Melimpah & 0,05 & 4 & 0,32 & Tersedia \\
\hline Jumlah Usaha Beraneka Ragam & 0,02 & 4 & 0,08 & Banyak \\
\hline Pasar dan Pemasaran Terbuka Lebar & 0,05 & 3 & 0,15 & Ada \\
\hline Keberadaaan Lokasi Usaha & 0,02 & 3 & 0,21 & Ada \\
\hline Lapangan Usaha Tenaga Kerja & 0,05 & 3 & 0,15 & Tersedia \\
\hline Sub Total & 0,64 & & 2,67 & \\
\hline \multicolumn{5}{|l|}{ Threat (T) } \\
\hline Persaingan Pasar Usaha Kecil & 0,05 & 1 & 0,05 & High Competicion \\
\hline Kondisi Ekonomi dan Politik/Keaman & 0,04 & 2 & 0,18 & Kurang Aman \\
\hline Konflik Ruang dengan kegiatan perikanan & 0,03 & 1 & 0,07 & Rawan \\
\hline $\begin{array}{l}\text { Pencemaran Lingkungan karena tidak ada } \\
\text { perawatan }\end{array}$ & 0,03 & 1 & 0,03 & Banyak yang rusak \\
\hline $\begin{array}{l}\text { Koordinasi antara Pelaku usaha dan beberapa } \\
\text { sektor lemah }\end{array}$ & 0,02 & 2 & 0,18 & Beda Visi \\
\hline $\begin{array}{l}\text { Pemerintah Membuat Program Hanya Sebatas } \\
\text { Slogan }\end{array}$ & 0,05 & 1 & 0,03 & Kurang Sejalan \\
\hline Koordinasi $\quad$ Antara Dunia Usaha dgn & 0,06 & 1 & 0,02 & Tidak sejalan \\
\hline
\end{tabular}


JURNAL AKUNTANSI, KEUANGAN DAN AUDIT

\begin{tabular}{|l|c|c|c|c|}
\hline Pemerintah tak sejalan & & & & \\
\hline $\begin{array}{l}\text { Softs kill dan Hardskill Masyarakat Ekonomi } \\
\text { Lokal }\end{array}$ & 0,03 & 2 & 0,1 & $\begin{array}{c}\text { Kurang Perhatian } \\
\text { Pemerintah }\end{array}$ \\
\hline Sub Total & 0,36 & & 0,27 & \\
\hline Jumlah Total S dan W & 1,00 & & 2,00 & \\
\hline
\end{tabular}

Sumber Data: hasil Penelitian 2015

d. Faktor - Faktor Penghambat Ekonomi Masyarakat Lokal Ada beberapa faktor penghambat yang dalam pengembangan Ekonomi Lokal Masyarakat Kelapa Lima Yakni:

1. Tipologi Masyarakat Kelapa Lima Yang heterogen dan Tingkat pengangguran yang tinggi dan Peran pemerintah masih belum maksimal dalam membantu pengembangan ekonomi Lokal di daerah ini

2. Dalam aspek bauran pemasaran Masing masing Pengusaha, Pedagang dan Pemilik rumah Makan berusaha sendiri sendiri dalam mengembangan Usahanya

3. Banyak Ukm yang belum Mendaftarkan Izin Usaha nya karena Prosesnya sangat berbelit belit

4. Modal yang dimiliki hanya sebatas untuk kelangsungan hidup sehingga usaha tidak dapat berkembang dgn baik.

5. Dikawasan kelapa lima sudah terlalu banyak supermarket besar sehingga pedagang kaki lima tak mampu bersaing dalam hal harga barang

6. Tidak adanya pembinaan dan pelatihan bagi masyarakat ekonomi lokal 


\section{e. Model Penciptaan Lapangan Pekerjaan melalui pengembangan Ekonomi Lokal}

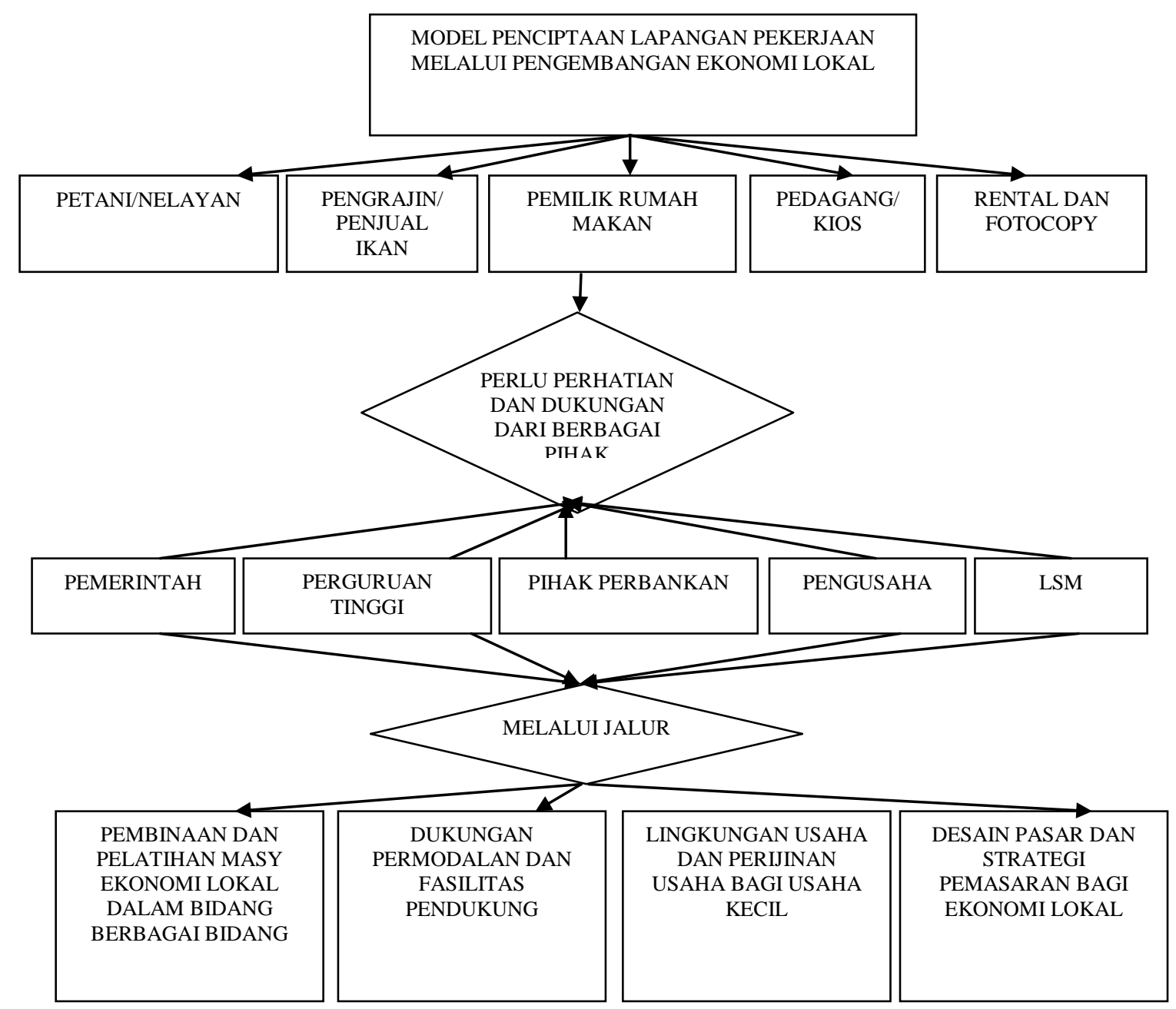

\section{KESIMPULAN DAN SARAN 1. KESIMPULAN}

Berdasarkan hasil analisis dan pembahasan secara umum dapat disimpulkan bahwa potensi sumberdaya ekonomi lokal yang 


\section{Desember}

berdaya tarik dan berdaya saing tinggi yang dapat membuka lapangan kerja bagi masyarakat kelapa lima adalah: 1) Ditinjau dari sektor usahanya berturutturut adalah : perikanan, perdagangan, industri rumah tangga dan jasa, pertanian dan peternakan sangat menjanjikan karena lokasi daerahnya sangat strategis. 2) Ditinjau dari Jenis produk unggulannya berupa hasil Kelautan berupa ikan, makanan \& minuman tradisional, kerajinan gula lempeng, jasa fotocopy dan Rental serta rumah makan. 3). Hasil analisa SWOT menjelaskan bahwa ada beberapa kekuatan dan kelemahan masyarakat ekonomi lokal yakni sumber daya ekonomi lokal sangat potensi dan jumlah bahan baku serta tenaga kerja yang melimpah namun tidak adanya perhatian dan dukungan dari pemerintah dalam mengembangkan masyarakat didaerah ini, sementara itu peluang Dan ancaman yang ada di kecamatan kelapa lima diantaranya adalah minat dan kebutuhan masyarakat semakin banyak dan daya saing semakin tinggi

\section{SARAN}

Berdasarkan beberapa kesimpulan diatas maka diperlukan beberapa saran sbb:

1. Diperlukan tindakan perencanaan pengembangan ekonomi lokal secara terpadu dan berkelanjutan dari pihak pemerintah daerah, Pihak Bank, Pihak Pengusaha, LSM dan perguruan Tinggi dalam menguatkan kemampuan sektor usaha informal.

2. Peningkatan koordinasi lintas sektor antar SKPD Kota Kupang terkait dengan upaya pengentasan kemiskinan melalui penciptaan lapangan kerja di sektor usahausaha produktif yang merupakan produk unggulan yang memiliki daya tarik dan daya saing tinggi.

3. Tempat pengembangan sentra sentra produk unggulan yang berbasis pada potensi lokal seperti sektor pertanian dan agri bisnis, sektor kelautan dan Sektor wisata, Perdagangan dan Jasa di masing masing di kelurahan dan pengelolaan pasar di masing masing kelurahan di desain lebih baik lagi.

4. perlu pembinaan dan pelatihan bagi Usaha Kecil sektor Informal Ekonomi Lokal

\section{DAFTAR PUSTAKA}

Badan Pusat Statistik, Kabupaten kupang/ NTT Dalam Angka 2009, NTT.

Blakely, Edward J. (1994) Planning Local Economic Development (Theory and Practice). California, Sage Publications, Inc

Glasson, John. (1990) An Introduction to Regional Planning Concepts, Theory and Practice. Melbourne, Hutchinson.

Haeruman, H (2000), Peningkatan Daya Saing Industri Kecil, Graha Sucofindo, Jakarta

\section{POLITEKNIK NEGERI KUPANG}




\section{Desember}

Harian Pos Kupang, 2010

Ishemat Soerianegara. 1977. Pengelolaan Sumber daya alam. Bogor: Pasca Sarjana IPB.

Kartasasmita, Ginanjar. Pembangunan Rakyat Pertumbuhan Pemerataan. Jakarta, PT. Pusaka Cidesindo. (1996) Nazi Untuk Memadukan Dan Pedoman

Kuncoro, Mudrajat. (2004) Otonomi dan

Pembangunan Daerah:

Reformasi, Perencanaan, Sugiyono. (2001). Metodologi Penelitian Strategi dan Peluang. Jakarta, Airlangga Munir, Risfan. (2007) Pengembangan Pariwisata
Ekonomi Lokal Partisipatif: Masalah, kebijakan dan Panduan Pelaksanaan Kegiatan. Jakarta, Local Governance Support Program (LGSP)

M. 2005. Metode Penelitian. Cetakan Keenam. Bogor: Ghalia Indonesia

Penelitian dan Pengabdian Masyarakat Edisi IX, DP2M, 2013

Philip Khotler, Strategi pengembangan produk, 2004

Bisnis. Jakarta: Alfabeta

10 tahun 2009 Tentang 